\title{
The effectiveness of the non-free plastic bag policy to reduce plastic waste in the community of Padang
}

\author{
Novia Wirna Putri ${ }^{1}$, Septia Pristi Rahmah ${ }^{1}$, Defriman Djafri ${ }^{1}$, Irene Sandra Olivia ${ }^{1}$, and Ulfah Winanda Putri ${ }^{1}$ \\ ${ }^{1}$ Faculty of Public Health, Andalas University, Padang, Indonesia
}

\begin{abstract}
The waste generation of Padang City at the Final Processing Site (TPA) is 495.50 tons/day, and the amount of unmanaged waste is 62.42 tons/day, of which $40 \%$ is plastic waste. Efforts to reduce the use of plastic bags have begun in Padang, referring to Perwaliko number 36 of 2018. Shopping centers and modern stores must use plastic shopping bags that meet SNI no later than December 31, 2020 , especially in various retail and contemporary shopping centers. This study aimed to analyze the relationship between the effectiveness of plastic use policies and the decrease in the use of plastic bags in people who shop at modern retailers in Padang City. This type of research is quantitative with a cross-sectional design. The number of samples is 116 respondents who shop at modern shopping centers, namely Matahari Dept. Store, Food Mart Padang, Ramayana Padang and SPAR Padang. Data analysis used univariate and bivariate analysis. The results showed that $46.6 \%$ of respondents stated that the plastic bag policy was not adequate, and $46.6 \%$ of respondents stated that there was no reduction in plastic bags. There is a significant relationship between the effectiveness of the plastic bag policy and the decrease in the use of plastic bags in the people of Padang City $(p=0,029)$. With this paid plastic bag policy, government, retailers, and the public will be more concerned with the environment.
\end{abstract}

\section{Introduction}

Plastic bags are bags used as wrappers to carry shopping items in food, drinks, clothing, and other household items. The nature of cheap, practical, and compact plastic bags makes plastic bags increasingly out of control. The world's population can use 500 million to 1 billion plastic bags in one year. Everyone uses 150 plastic bags every year.2011 To make that much plastic requires 12 million barrels of oil and 14 million tree trunks that must be cut down as the basic raw materials for making it. Of course, the higher use of plastic bags will be followed by an increase in the amount of plastic waste. Plastic bags that are not used will be thrown away, even though it takes hundreds of years to decompose [2]. In the last ten years, the amount of plastic waste generated has continued to increase significantly. Indonesian people use around 9.8 billion pieces of plastic bags every year. Almost $95 \%$ of the use of plastic bags becomes plastic waste (KLHK, 2016).

The population of Padang City in 2018 reached 939,112 people, with a population density of 1,351 people $/ \mathrm{km} 2$. This population is accompanied by the generation of Padang City waste at the Final Processing Site (TPA) as much as 495.50 tons/day and unmanaged waste as much as 62.42 tons/day. In 2019, the population of Padang City increased to 950,871 people, with a waste generation of 624.24 tons/day This shows that the increase in population goes hand in hand with the increase in the number of municipal solid waste generation.

Plastic bags take a long time, even thousands of years, to decompose completely. The decomposition of plastic in the soil into plastic particles can contaminate soil and groundwater. If burned, plastic will produce toxic fumes harmful to health because it will decompose in the air as dioxin compounds that are very dangerous if inhaled. Throwing plastic into rivers and seas can damage habitats in rivers and seas [2].

Therefore, it is crucial to manage plastic waste. To reduce environmental problems from the use of plastic bags, several countries such as Australia, Italy, the United States, Tanzania, and Ireland have used taxation or bans on the production and use of plastic bags for shopping or other purposes [5].

In Indonesia, the Ministry of Environment and Forestry (KLHK) has issued a policy aimed at reducing the generation of plastic waste through the Circular Letter of the Directorate General of Waste Management, Hazardous and Toxic Waste and Materials of the Ministry of Environment and Forestry Number: SE-06/PSLB3PS/2015 concerning Anticipatory Measures Application of the Paid Plastic Bag Policy in Modern Retail Businesses and Circular Letter Number S. 1230/ PSLB3PS/2016 concerning the price and mechanism for the application of paid plastic bags are the basis for the implementation of the paid plastic bag policy in the modern market (KLHK, 2016). Plastic bags are no longer

\footnotetext{
* Corresponding author: noviawina.skm@gmail.com
} 
given free of charge by retailers to consumers. If the consumer needs a plastic bag, the consumer must buy a plastic bag from the shopping place. The Ministry of Environment and Forestry has reduced plastic waste with a paid plastic bag trial program. The program trial started on February 21, 2016, in conjunction with the commemoration of National Waste Care Day. With the existence of paid plastic bags, people will bring their shopping bags, not just throwing away plastic bags that have been given free of charge by supermarkets/other retail traders.

Padang City Government support for plastic waste management efforts in the form of the issuance of Padang Mayor Regulation No. 36 of 2018 concerning Control of the Use of Plastic Shopping Bags. This regulation explains that one of the government's policies in reducing waste, especially plastic waste, is applying a plastic bag policy that is not free in all shopping centers, modern shops, and traditional markets in Padang City. Modern shopping centers and shops must use plastic shopping bags that fully meet SNI no later than 31 December 2020. For this reason, it is necessary to research the effectiveness of the policy of using non-free plastic bags to reduce their use in people who shop at modern retail in the city of Padang.

\section{Method}

The type of research used is analytical research using a cross-sectional design. The population in this study were all people who shopped at modern retailers in Padang who applied the non-free shopping cart policy, namely Matahari Dept. Store Padang, Foodmart Padang, Ramayana Padang, and SPAR Padang, whose population is unknown. The number of samples in this study was 116 respondents. The location of this research is in a modern shopping center that has implemented a plastic bag policy that is not free, namely Matahari Dept. Store Padang, Foodmart Padang, Ramayana Padang, and SPAR Padang. The research variables are the effectiveness of the policy on the use of non-free plastic bags and the decrease in the use of single-use plastic bags. Primary data is collected directly through the distribution of questionnaires to respondents.

Univariate analysis was used on each of the variables studied with a frequency distribution table accompanied by an explanation, namely the frequency distribution of the effectiveness of the policy on the use of non-free plastic bags and the decrease in the use of plastic bags. Bivariate analysis was used to see the relationship between the independent and dependent variables using the chi-square statistical test at the $95 \%$ confidence level $(\mathrm{p}<0.05)$.

\section{Result}

Table 1 shows an overview of the frequency distribution of respondent characteristics like gender, age, and education. Table 1 shows that female respondents $(89.7$ $\%)$ were more than male respondents $(10,3 \%)$. Based on age, more respondents were categorized as late adolescents aged 17-25 years (53,4 \%). Based on education, most of the respondents have a senior high school education, namely $58.6 \%$.

Table 1. Respondent Characteristic

\begin{tabular}{|l|l|l|}
\hline Respondent Characteristics & F & \% \\
\hline Gender & & \\
\hline Male & 12 & 10,3 \\
\hline Female & 104 & 89,7 \\
\hline Age & & \\
\hline $17-25$ years & 62 & 53,4 \\
\hline $26-35$ years & 18 & 15,5 \\
\hline $36-45$ years & 15 & 12,9 \\
\hline 46-55 years & 18 & 15,5 \\
\hline $56-65$ years & 3 & 2,6 \\
\hline Education & & \\
\hline Elementary & 2 & 1,7 \\
\hline Middle school & 3 & 2,6 \\
\hline High school & 68 & 58,6 \\
\hline Above college & 43 & 37,1 \\
\hline
\end{tabular}

Based on the results of the study, it can be described the frequency distribution of policy effectiveness in the people who shop at modern retailers in the city of Padang, can be seen in Table 2 below:

Table 2. Description of Policy Effectiveness Frequency Distribution to the Padang Community

\begin{tabular}{|c|c|c|c|}
\hline \multirow[b]{2}{*}{ No } & \multirow[b]{2}{*}{ Statement } & \multicolumn{2}{|c|}{ Evaluation } \\
\hline & & $\begin{array}{l}\text { Yes } \\
(\%)\end{array}$ & $\begin{array}{c}\text { No } \\
(\%)\end{array}$ \\
\hline 1 & $\begin{array}{l}\text { There has been a notification from the } \\
\text { government regarding the paid plastic } \\
\text { bag policy }\end{array}$ & 59,5 & 40,5 \\
\hline \multirow[t]{2}{*}{2} & $\begin{array}{l}\text { There has been a notification from the } \\
\text { supermarket regarding the paid plastic } \\
\text { bag policy }\end{array}$ & 62,1 & 37,9 \\
\hline & $\begin{array}{l}\text { Supermarkets offer alternative options } \\
\text { for shopping bags other than plastic }\end{array}$ & 58,6 & 41,4 \\
\hline 3 & $\begin{array}{l}\text { The application of the paid plastic bag } \\
\text { policy by the supermarket to buyers is } \\
\text { correct }\end{array}$ & 71,6 & 28,4 \\
\hline \multirow{2}{*}{4} & $\begin{array}{c}\text { The price of a plastic bag is Rp. } 200 \text { - } \\
\text { according to your current economic } \\
\text { condition }\end{array}$ & 89,7 & 10,3 \\
\hline & $\begin{array}{l}\text { The paid plastic bag policy is very } \\
\text { appropriate when the volume and types } \\
\text { of waste are increasingly diverse today }\end{array}$ & 87,1 & 12,9 \\
\hline \multirow[b]{2}{*}{5} & $\begin{array}{l}\text { Paid plastic bag policy can reduce } \\
\text { the use of plastic bags }\end{array}$ & 77,6 & 22,4 \\
\hline & $\begin{array}{l}\text { After finishing shopping, the plastic } \\
\text { bags have been recycled by business } \\
\text { actors/supermarkets }\end{array}$ & 56,0 & 44,0 \\
\hline \multirow[t]{2}{*}{6} & $\begin{array}{l}\text { Paid plastic bag policy has an } \\
\text { impact on a clean and healthy } \\
\text { environment }\end{array}$ & 85,3 & 14,7 \\
\hline & Bring your shopping bag & 78,4 & 21,6 \\
\hline
\end{tabular}

Based on Table 2 shows that $89.7 \%$ of the people of Padang City agree that the price of plastic bags is Rp. 200 - according to the current economic condition of the community. As many as $87.1 \%$ of the people of Padang 
City agree that the paid plastic bag policy is very appropriate when the volume increases and the current type of waste. As many as $85.3 \%$ of the community agree that the paid plastic bag policy impacts a clean and healthy environment.

The frequency distribution of the effectiveness of the policy on the use of plastic bags for people who shop at modern retail in Padang City can be seen in the following table:

Table 3. Frequency Distribution of Policy Effectiveness to the people of the city of Padang

\begin{tabular}{|l|l|l|}
\hline $\begin{array}{l}\text { The Effectiveness } \\
\text { Policy }\end{array}$ & Frequency (f) & Percentage (\%) \\
\hline Ineffective & 54 & 46,6 \\
\hline Effective & 62 & 53,4 \\
\hline Total & 116 & 100,0 \\
\hline
\end{tabular}

Table 3 shows that as many as 54 people (46.6\%) of respondents stated that the policy on paid plastic bags was not effective. The frequency distribution of the decrease in the use of plastic bags among people who shop at modern retail in Padang City (Table 4):

Table 4 Frequency Distribution of Decreased Use of Plastic Bags in Padang City Community

\begin{tabular}{|l|l|l|}
\hline $\begin{array}{l}\text { Decrease in the } \\
\text { use of plastic } \\
\text { bags }\end{array}$ & Frequency (f) & Percentage (\%) \\
\hline Bad & 54 & 46,6 \\
\hline Good & 62 & 53,4 \\
\hline Total & 116 & 100,0 \\
\hline
\end{tabular}

Table 4 shows that as many as 54 people (46.6\%) respondents stated that the decrease in plastic bags was not good. The frequency distribution of the decrease in the use of plastic bags in people who shop at modern retailers in the city of Padang in Table 5:

Table 5 Description of Frequency Distribution of Decreased Bag Usage Plastic in Padang City

\begin{tabular}{|l|l|l|l|}
\hline \multirow{2}{*}{ No } & Statement & \multicolumn{2}{|l|}{ Evaluation } \\
\cline { 3 - 4 } 1 & $\begin{array}{l}\text { Before there was a paid } \\
\text { plastic bag policy, I didn't } \\
\text { bring my shopping bag }\end{array}$ & 80,2 & Disagree(\%) \\
\hline \multirow{2}{*}{2} & $\begin{array}{l}\text { After there was a policy } \\
\text { and an appeal for paid } \\
\text { plastic bags, I brought my } \\
\text { shopping bag }\end{array}$ & 70,7 & 29,3 \\
\hline \multirow{2}{*}{3} & $\begin{array}{l}\text { Shopping bags that you } \\
\text { bring are reusable, more } \\
\text { durable, and more } \\
\text { economical than buying } \\
\text { plastic shopping bags } \\
\text { every time you shop }\end{array}$ & 85,3 & 14,7 \\
\hline
\end{tabular}

Table 5 shows that $95.7 \%$ of respondents agree that supermarkets must provide types of shopping bags other than environmentally friendly plastic, $87.9 \%$ of respondents agree that supermarkets are the right party for implementing a paid plastic bag policy to reduce the use of plastic bags. As many as $86.2 \%$ of respondents agree that the selling price of plastic bags is worth Rp. 200, - is considered cheap. As many as $80.2 \%$ of respondents agreed that before there was a paid plastic bag policy, I did not bring my shopping bag, and as many as $70.2 \%$ of respondents agreed that after there was a policy and an appeal for paid plastic bags, I brought my shopping bag. There was a $50.9 \%$ decrease in single-use plastic bags after the policy of using non-free plastic bags.

\subsection{The Relationship between the Effectiveness of the Plastic Bag Policy and the Reduction in the Use of Plastic Bags}

Table 6 shows the relationship between the Effectiveness of the Plastic Bag Policy and the reduction in the use of plastic bags:

Table 6. The Relationship between the Effectiveness of the Plastic Bag Policy and the Reduction in the Use of Plastic Bags

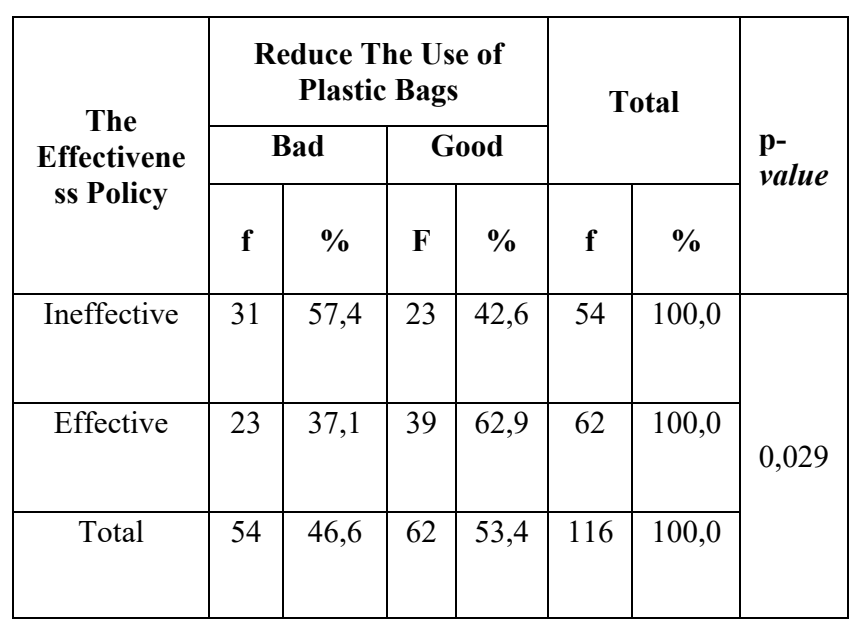

Table 6 shows that more respondents stated that the policy of using plastic bags was not effective in reducing the use of plastic bags in daily life, namely 31 people $(57.4 \%)$, compared to respondents who stated that the policy of using plastic bags was effective in reducing the use of plastic bags. Plastic in daily life has as many as 23 people $(37.1 \%)$. The statistical analysis shows a relationship between the effectiveness of the plastic bag policy and a decrease in the use of plastic bags ( $p$-value $=0.029$ ).

\section{Discussion}

\subsection{The Effectiveness of Plastic Bag Policy}

Based on the results of the univariate analysis on the effectiveness of the non-free plastic bag policy, 54 people $(46.6 \%)$ of respondents stated that the policy on paid plastic bags was not effective, and 62, 9\% said it was effective. Research by Asmuni (2015) states that the No Plastic Bag Day (NPBD) program in Malaysia has made consumers avoid the use of plastic bags by $52.3 \%$. This program has influenced customers to use reusable shopping bags. (Asmuni, Hussin, Khalili, \& Zain, 2015) . 
The Malaysian government in 2011 launched the Day Without Plastic Bags Campaign. The goal is to reduce plastic bags that harm the environment. All retail, supermarkets, and hypermarkets participate in the program. Stores that do not provide plastic bags encourage customers to bring their bags or purchase ecofriendly bags. Some stores provide paper bags or synthetic fiber bags that can be reused several times. They strengthened the ban on plastic bags with a levy fee of MYR 0.20 or around 700 rupiahs (Asmuni, Hussin, Khalili, \& Zain, 2015). The fee for the tax retribution is channeled to charity (Hong, 2011) or used for environmental conservation activities. However, the government is allowing the use of new plastic bags for traditional markets, restaurants, and night markets for hygiene when bringing groceries and wet food (Zen, Ahamad, \& Omar, 2013).

Based on the description of the frequency distribution of respondents' statements, $89.7 \%$ of the people of Padang City agree that the price of plastic bags is Rp. 200 according to the current economic condition of the community, as many as $87.1 \%$ of the people of Padang City agree that the paid plastic bag policy is very appropriate when it is getting worse. The current volume and type of waste increases, and as many as $85.3 \%$ of the community agree that the paid plastic bag policy impacts a clean and healthy environment.

The implementation of plastic bag policies in developed countries started in the early 1990s, namely by imposing taxes in Germany and Denmark. Although Germany and Denmark were the first countries to impose a plastic bag tax in 1991 and 1994, only Denmark can pioneer plastic bag policies. (Knoblauch, Linda, \& Stein, 2018). In the southern states of Europe, the fact that plastic bag waste is much more visible and dangerous due to limited collection and recycling of waste has led policymakers to adopt plastic bag laws. (Knoblauch, Linda, \& Stein, 2018)

The Government implements a paid plastic bag policy to reduce environmental pollution from plastic waste. During the trial of paid plastic bags, the Government, the National Consumer Protection Agency (BPKN), the Indonesian Consumers Foundation (YLKI), and the Indonesian Retail Entrepreneurs Association (APRINDO) agreed that the selling price of plastic bags was at least Rp. 200-, per bag including additional tax. Value (VAT). After the trial runs for at least three months, the price of plastic bags is evaluated by the Government, Local Government, and APRINDO. The agreement between retailers, the Government, BPKN, YLKI, and APRINDO that the plastic bags provided are chosen have the most negligible environmental impact and must meet national standards issued by the Government or independent institutions. APRINDO is committed to supporting the provision of incentives to consumers, environmental management through corporate social responsibility programs with respective regulations and waste management. This policy also applies to modern retail businesses that are not members of APRINDO (Bahagia, Yunita, \& Susanti, 2019).

Applying the policy of not-free plastic bags has both positive and negative impacts from an environmental and economic perspective. From an environmental perspective, this policy has a positive value because it can preserve the environment by reducing plastics that can pollute the environment, water, soil, and air sources. From an economic point of view, this policy can be detrimental to the community because the public must pay a mediumsized plastic bag fee of between Rp. $200-\mathrm{Rp}$. 250. If people spend a lot of money, of course, the money spent on buying plastic bags will increase (Bahagia, Yunita, \& Susanti, 2019). This policy is straightforward to implement. It is enough for people to bring their shopping bags, then they can be involved in this policy and the consequences if they do not bring their shopping bags are not too burdensome, which only costs Rp. 200,(Octavianti, Koswara, \& Sari, 2016).

This policy is expected to change people's behavior to reduce the use of plastic bags starting from simple things, namely when shopping. This policy conveys a message to bring shopping bags from home. This policy is implemented as an innovation present in the community to shape and change people's behavior in a better direction so that environmental and ecosystem sustainability is maintained, disaster prevention, and reduction of the circulation of plastic waste (Octavianti, Koswara, \& Sari, 2016). This paid plastic bag policy must, of course, be known by the broader community so that it will not cause polemics and question marks in its implementation. News of this policy is also communicated through many mass media, both traditional and electronic. The role of the media is still a very effective and favorite communication strategy because the reach of the media is extensive, not only on a local scale but also nationally, even internationally (Lusnita, 2019).

With this much news, it is hoped that the public will understand the intent and purpose of implementing this paid plastic bag policy and that the ultimate goal of reducing plastic waste can be achieved. After the communication from KLHK to Aprindo and Aprindo to its members, the most important thing is how retailers communicate with consumers. Therefore, the Ministry of Environment and Forestry requires retailers to install a form of communication at each outlet in an announcement or statement that plastic bags are no longer free. Following the method chosen by the Ministry of Environment in its communication strategy, the Ministry of Environment and Forestry created infographic information such as the one below, which provides education about waste in its announcements to provide an understanding to consumers why plastic bags are no longer given free of charge (Lusnita, 2019) (Asmuni, Hussin, Khalili, \& Zain, 2015). One way to increase effectiveness and community participation is to foster a culture of carrying bags when shopping.

\subsection{Decreasing the Use of Plastic Bags}

Table 4 shows that $95.7 \%$ of respondents agree that supermarkets must provide types of shopping bags other than environmentally friendly plastic, $87.9 \%$ of respondents agree that supermarkets are the right party for implementing a paid plastic bag policy to reduce the use 
of plastic bags. As many as $86.2 \%$ of respondents agree that the selling price of plastic bags is worth Rp. 200, - is considered cheap. Many consumers prefer to buy plastic shopping bags when shopping. Therefore, the government needs to reconsider the price of plastic bags that are recommended to retailers. According to Novianti and Kartika, the recommended price to reduce the use of plastic bags is around Rp. 500 - Rp. 1000. The government should continue to socialize and provide an understanding of the paid plastic bag policy to strengthen consumers' desire to reduce the use of plastic bags (Astuti, 2016). As many as $80.2 \%$ of respondents agreed that before a paid plastic bag policy, they did not bring a shopping bag. As many as $70.2 \%$ of respondents agreed that they brought shopping bags after a policy and an appeal for paid plastic bags. There was a $50.9 \%$ decrease in single-use plastic bags after the policy of using non-free plastic bags. This change shows that implementing the plastic bag policy is changing consumer behavior.

The reduction of plastic waste in Indonesia cannot be calculated because it has only just begun, but there have been reports of its implementation in other countries. In China, the paid plastic bag policy was implemented in February 2008 in all regions of China. This plastic bag restriction covers the production, sale, and use of plastic bags. In addition, these plastic bags should not be distributed for free. Those who need it have to buy it. After three years of implementing a paid plastic bag policy, China reported that the use of plastic bags had decreased by $2 / 3$ from the previous, which was 60 thousand tons of plastic. This amount of plastic is equivalent to 3.6 million tons of oil or 5 million tons of coal and cuts $\mathrm{CO} 2$ emissions by more than 10 million tons (Widhi, 2016). The decline in the use of plastic bags with the implementation of a paid plastic bag policy also occurred in South Africa. This policy was implemented in May 2003. In 2010, a study from the University of Cape Town stated that there had been a $44 \%$ decline in plastic bag consumption since the plastic bag restriction policy was implemented (Widhi, 2016). A similar thing has happened in the United States, which has implemented this policy since 2014. Some stores charge 10 US cents or the equivalent of Rp. 1385 for the use of pre-packaged, recyclable plastic bags (Tjahjono, 2016). In Hong Kong, people who shop and use plastic bags have to pay 50 cents. With a paid plastic bag program, these efforts can reduce plastic consumption by up to $73 \%$ (KLHK, 2016).

The UK has implemented a paid use of plastic bags in shops since October 2015. Shops charge 5 pence or equivalent to IDR 985 for each use of a plastic bag. The UK was the last country in the UK to implement the policy (Wales in 2011, Scotland and Northern Ireland in 2014). Within three years of its implementation, this paid plastic policy has reduced plastic consumption by up to $80 \%$ in Wales (Thomas, Sautkina, Wolstenholme, \& Whitmarsh, 2019). Thus, the implementation of the paid plastic bag policy that has been implemented in several countries in the world has a positive impact on the environment. A significant decrease can see in the number of plastic bags used in these countries. In Indonesia, the implementation of the paid plastic bag policy is also expected to be able to contribute to reducing the number of plastic bags.

\section{Conclusion}

The generation of plastic waste in Indonesia is getting more and more out of control. It can pollute the environment because of the nature of plastic which is difficult to biodegrade in the long term. Plastic waste is also harmful to the health of living things. Plastics are made from materials that are carcinogenic if they enter the food eaten. Then, replacing plastic with biodegradable plastic and reducing plastic use by implementing a paid plastic bag policy. Applying paid plastic bags in Indonesia was carried out from February 21, 2016, to June 5, 2016. It is hoped that the implementation of this policy can reduce the use of plastic bags in Indonesia, as in other countries that have implemented this policy before.

The existence of a paid plastic bag policy is expected to encourage the government, retailers, the public, and the media to be more concerned about the environment. The government is expected to make policies and rules regarding reducing the use of plastic bags, starting from reducing production, storage, sales, distribution to the use of plastic. Retailers are expected to implement rules and systems to reduce the use of plastic bags and educate consumers. Retailers can provide non-plastic shopping bags with attractive designs and large sizes.

The community should implement a plastic diet lifestyle starting at home and participate in educating and socializing together as a community. The role of the media is needed to make this policy successful by disseminating the plastic bag diet solution and the reasons for doing so.

Thanks to the people of Padang City who have participated in this research. Thank you also to fellow lecturers in the K3 Kesling department, IKM Study Program, and the entire academic community of the Faculty of Public Health, Andalas University, for their support and cooperation.

\section{References}

1. S Asmuni, Hussin, N. B., Khalili, J. M., Z. M. Zain, Public Participation and Effectiveness of The No Plastic Bag Day Program in Malaysia. Procedia Social and Behavioral Sciences 168, 328 - 340 (2015)

2. Astuti, D.A. Application of Paid Plastic Bags as an Effort to Reduce the Use of Plastic Bags. R\&D, 12, 32-40 (2016).

3. Bahagia, Yunita, I., \& Susanti, R. M. Analysis of Paid Plastic Bag Policy Implementation at Modern Retail Banda Aceh. Porch Technique, 549 - 556 (2019).

4. Hong, L. C. (2011). Environmental tax laws in Malaysia today. Malaysian Accountancy Research and Education (MAREF) Review 1(2), 9-10 (2011)

5. Jalil, M. A., Mian, M. N., \& Rahman, M. K.. Using plastic bags and its damaging impact on environment and agriculture: An alternative proposal. International Journal of Learning \& Development, 3(4), 1-14 (2013) 
6. Ministry of Environment.). 2019 National Waste Management Information System. Retrieved from http://.sipsn.menlhk.go.id (2019)

7. KLHK17 Cities Will Implement Paid Plastic Bags. Jakarta:Director General of Waste, Waste and B3 Management . (2016).

8. Knoblauch, D., Linda, M., \& Stein, U. (2018). Developing Countries in The Lead - WHat Drives The Diffusion of Plastic Bag Policies? Sustainability, $1-24$.

9. Lusnita, N. Plastic Waste Reduction Program Through Paid Plastic Bag Policy in Modern Retail. Servites 1(1), 12 - 24 . (2019)

10. Octavianti, M., Koswara, I., \& Sari, D. YCharacteristics of Plastic Bag Policy Innovation Not Free for Housewives in the City of Bandung. Communication 8(2), 134-146 . (2016).
11. Safitri, P., Winda, S., \& Mochamad, Z. (2018). Statistik Lingkungan Hidup Indonesia. Jakarta: Badan Pusat Statistik Indonesia.

12. Thomas, G. O., Sautkina, E., Wolstenholme, E., \& Whitmarsh, L. (2019). The English Plastic Bag Charge Changed Behavior and Increased Support for Other Charges to Reduce Plastic Waste. Frontiers in Psychology 10, 266.

13. Tjahjono, S. (2016, Maret 16). Pengelolaan Limbah Plastik "Fosil" Masa Depan. Diambil kembali dari http://print.kompas.com.

14. Widhi, N. (2016, Oktober 10). Tas Plastik Berbayar Rp. 200 di Indonesia. Bagaimana di Luar Negeri? Diambil kembali dari http://news.detik.com/berita/31479.

15. Zen, L. S., Ahamad, R., \& Omar, W. (2013). No Plastic Bag Campain Day in Malaysia and The Policy Implication. Development and Sustainability 15 (5), $1259-1269$. 